\title{
Critical Thinking Dispositions of Pre-Service Mathematics Teachers
}

\begin{tabular}{|c|c|}
\hline \multicolumn{2}{|c|}{ Erzurum Vocational School, Ataturk University, Erzurum, Turkey } \\
\hline Article history & In today's vastly changing world, many organizations such as The \\
\hline $\begin{array}{l}\text { Received: } \\
09.08 .2016\end{array}$ & $\begin{array}{l}\text { Partnership for } 21 \text { st Century Skills (P21) have advocated that the key } \\
\text { performance outcomes around which curricula and assessments should be }\end{array}$ \\
\hline $\begin{array}{l}\text { Received in revised form: } \\
11.09 .2016\end{array}$ & $\begin{array}{l}\text { focused are critical thinking, reasoning, communication and } \\
\text { media/information/technology literacy in mathematics. Thus, students } \\
\text { will need to take into account both the core academic knowledge and the }\end{array}$ \\
\hline $\begin{array}{l}\text { Accepted: } \\
20.09 .2016\end{array}$ & higher order thinking skills to be successful in college, life and career. \\
\hline & thinking dispositions. 202 students who were enrolled in the department \\
\hline $\begin{array}{l}\text { critical thinking disposition, } \\
\text { pre-service mathematics } \\
\text { teacher, critical thinking }\end{array}$ & $\begin{array}{l}\text { of mathematics education at a university in Turkey completed a Turkish } \\
\text { version of the "California Critical Thinking Dispositions Inventory" } \\
\text { (CCTDI). The scale has six subscales (Open-mindedness, inquisitiveness, } \\
\text { systematicity, truth seeking, analyticity, and self-confidence). The results } \\
\text { revealed that the majority of students had moderate critical thinking } \\
\text { disposition. Strong positive relationships among all six subscales were } \\
\text { determined. Further, there were significant differences in students' critical } \\
\text { thinking disposition based on gender and grade level. }\end{array}$ \\
\hline
\end{tabular}

\section{Introduction}

In today's vastly changing world, many organizations such as The Partnership for 21 st Century Skills (P21) have advocated that the key performance outcomes around which curricula and assessments should be focused are critical thinking, reasoning, communication and media/information/technology literacy in mathematics. Thus, students will need to take into account both the core academic knowledge and the higher order thinking skills to be successful in college, life and career (Partnership for 21st Century Skills, 2011).

According to Yang, Chuang, Li, and Tseng (2014), critical thinking is one of the most important keys of the 21st century higher order thinking abilities and is a significant component of education (Browne \& Litwin 1987; Kong et al., 2014; Moore, 2013; Şendağ \& Odabaş1, 2009; Yeh, 2012).

Researchers have described critical thinking (CT) as "the ability to engage in purposeful, selfregulatory judgment" (Abrami et al., 2008), "reflective decision-making and thoughtful problem solving about what to believe and do thinking" (Ennis, 1987), "cognitive skills or strategies that increase the probability of a desirable outcome" (Halpern, 2003), and "the educational cognate of rationality" (Siegel, 1998).

One of the most important contributions on conceptualization of CT is done through "The American Philosophical Association Delphi Project" (Facione, Giancarlo, Facione, \& Gainen, 
1995). According to this project, critical thinking for educational purposes includes both cognitive skills and dispositions (Facione, 1990). Critical thinking disposition which is characterized as a "probing inquisitiveness, a keenness of mind, a zealous dedication to reason, and a hunger or eagerness for reliable information" includes seven sub-dispositions: openmindedness, inquisitiveness, systematicity, truth-seeking, analyticity, CT self-confidence, and cognitive maturity (Facione, 1990). Table 1 displays the definitions of these dispositions.

Table 1. Definition of elements of critical thinking dispositions (Facione, Giancarlo, Facione, \& Gainen, 1995).

\begin{tabular}{ll}
\hline Factor & Description \\
\hline $\begin{array}{l}\text { Open-mindedness } \\
\text { Inquisitiveness }\end{array}$ & $\begin{array}{l}\text { being tolerant to divergent views and sensitive to the possibility of one's own bias. } \\
\text { intellectual curiosity and eagerness for learning even when the application of the knowledge is } \\
\text { not readily apparent. } \\
\text { being organized, orderly, focused, and diligent in inquiry. } \\
\text { disposition of being eager to seek the best knowledge in a given context, courageous about asking } \\
\text { questions, and honest and objective about pursuing inquiry even if the findings do not support } \\
\text { Truth-seeking }\end{array}$ \\
$\begin{array}{l}\text { one's self-interests or one's preconceived opinions. } \\
\text { prizing the application of reasoning and the use of evidence to resolve problems, anticipating } \\
\text { potential conceptual or practical difficulties, and consistently being alert to the need to intervene. }\end{array}$ \\
Analyticity & $\begin{array}{l}\text { to trust the soundness of one's own reasoned judgments and to lead others in the rational } \\
\text { resolution of problems } \\
\text { being judicious in one's decision-making }\end{array}$ \\
Self-Confidence &
\end{tabular}

Over the past decade, a lot of research has investigated the importance of critical thinking dispositions (CTD) (Bell \& Loon, 2015; Lewis, 2012; Naber \& Wyatt, 2014; Ojewole, 2013; Racchini, 2007; Walter, 2013; Yang, Chuang, Li, \& Tseng, 2014). Researchers have reported that CTD are significant because they are a pre-requisite to the development of powerful critical thinking skills (Beyer, 1987; Ojewole, 2013). According to Kuhn (1999), a learners' disposition to think critically is a factor that should be examined with caution, since it leaves a lot of unaccounted variance. Studies point out that age, maturity, education and educational curriculum are important (Cohen, 2010; Lane-Patrice, 2013; Lewis, 2012). It has been also proposed that gender and previous experience may be two of the factors that affect students' CT development. Ojewole (2013) believe that experience may affect the CTD, since CT is thought to have a chronological developmental component. Studies have reported statistically significant (Huang \& Yeh, 2010; Lane-Patrice, 2013) and insignificant differences (Lewis, 2012) between the CTD and experience. King, Wood and Mines (1990) found that the rate of critical thinking development among males majoring in social and mathematical science is higher than the rate for females. Others (Burbach, Matkin, Quinn, \& Searle, 2012; Cohen, 2010) believe that gender may not influence CT skills or dispositions. It is inconclusive whether or not experience and gender have any influence on a students' CT development. Therefore, it is important to explore gender and experience differences on students' CTD.

Research related to CTD has grown rapidly in Turkey (Akgün \& Duruk, 2016; Bakır, 2015; Beşoluk \& Önder, 2010; Çetinkaya, 2011; Kökdemir, 2003; Tümkaya, 2011; Yenice, 2011). Regarding pre-service teachers' CTD, researchers have reported that the CTD levels of the preservice teachers are low (Bakır, 2015; Çetinkaya, 2011, Incikabi, Tuna, \& Biber, 2013) and medium (e.g., Çevik, 2013; Şen, 2009). Based on the analysis of demographic features of preservice teachers, the findings show that there is significant difference according to gender (Çetinkaya, 2011, Tümkaya, 2011; Yenice, 2011), age (Çubukçu, 2006; Kürüm, 2002) and grade (Çetinkaya, 2011; Zayıf, 2008). In summary, previous research suggests that pre-service teachers' CTD levels are low and medium and that there are significant and insignificant differences according to gender, age and grade. 
Although CTD literature has grown, there are little evidence that look at the CTD of the preservice mathematics teachers charged with developing CT skills and dispositions in students (Çevik, 2013; Incikabi, Tuna, \& Biber, 2013; Yüksel, Uzun, \& Dost, 2013). Thus, the purpose of the current study was to investigate pre-service mathematics teachers' CTD. Following research questions were attempted to answer in this study:

1. What are the CTD of pre-service mathematics teachers?

2. Are there the differences in the six factors that measure pre-service mathematics teachers' CTD based on demographic variables: gender and grade level?

3. Are there relationships among the six factors measured by The California Critical Thinking Disposition Inventory (CCTDI)?

\section{Methodology}

A descriptive research design was used to investigate pre-service mathematics teachers' CTD. Survey research model was used for collecting data in the study. A total of 202 preservice mathematics teacher consisted of the sampling of the study. Participants were students in the department of mathematics education at a university in Turkey during spring term of 2014-2015 academic years.

\section{Data sources}

The California Critical Thinking Disposition Inventory (CCTDI)

The original CCTDI developed by Facione and Facione (1992) is composed of 75 items, covering seven dimensions. The Turkish version of the CCTDI, which was modified to Turkish context by Kökdemir (2003) has been administered to measure the dispositions of an individual to solve problems and make decisions through critical thinking. The modified instrument was reduced to 51 items with 6-point Likert scale ranging from 1 (not true) to 6 (completely true) in the item-total correlation analysis 6 subscales: open-mindedness (12 items), inquisitiveness (8 items), systematicity (6 items), truth seeking ( 7 items), analyticity (11 items), and selfconfidence ( 7 items). The reported alpha reliability of the overall CCTDI is .88 (Kökdemir, 2003).

\section{Demographic Survey}

The demographic survey included biographical information such as gender, age and grade level. The Turkish version of the CCTDI and demographic survey were administered to all pre-service mathematics teachers during the first week spring term of 2014-2015 academic years to be used in measuring CTD.

\section{Data analysis}

The data analysis was carried out using descriptive statistics, independent samples t-test and analysis of variance. The descriptive statistics were used to see demographics of the students and general picture of subscales scores. An independent $t$ test was used to investigate mean differences between males and females on all six subscales. An analysis of variance was used to find out pre-service teachers' dispositions compared with their level of education. The Pearson correlation test was used to examine the relationships among the six factors measured by the CCTDI.

\section{Results}

\section{Demographics}

202 students joined in the study. After the data collection stage, 14 cases with missing data were removed from the data. The examination of the data exposed eighteen outliers that were removed. 89 out of 170 of the respondents were female. The sample included 1. year (17.3 $\%), 2$. year(20.8\%), 3. year(23.0\%), 4. year(17.9\%) and 5. year (21.0\%) students. 


\section{Research question 1}

The Turkish version of the CCTDI is scored by summing the items, and dividing the total by the number of items and multiplying by ten. Therefore the minimum and maximum scores are 60 and 360 since it has six subscales. The overall mean score of students ranged from 127 to $342(\mathrm{M}=267.5)$. According to Kökdemir (2003), a score between 240 to 300 indicates a positive CTD. Therefore, total scores show that pre-service mathematics teachers have moderate CTD.

Table 2 shows means and standard deviations for each CCTDI subscale. The highest mean scores were obtained by the analyticity subscale $(\mathrm{M}=5.02)$ and the inquisitiveness subscale $(M=4.67)$. The lowest mean value was yielded by the truth-seeking subscale $(M=3.32)$. (See Table 2)

Table 2. Descriptive statistics of CTD of pre-service mathematics teachers.

\begin{tabular}{lcc}
\hline CCTDI scales & $\mathrm{M}$ & SD \\
\hline Open-mindedness & 3.90 & .77 \\
Inquisitiveness & 4.67 & .68 \\
Systematicity & 4.18 & .68 \\
Truth-seeking & 3.32 & .91 \\
Analyticity & 5.02 & .50 \\
Self-Confidence & 4.32 & .80 \\
\hline
\end{tabular}

Table 3 shows the mean scores of pre-service mathematics teachers for items on openmindedness subscale. The highest mean score corresponds to item 7 which states that the tests that require thinking, not just memorization, were better for them. More than $75 \%$ of students thought that this statement was mostly true, true or completely true. Over $70 \%$ of the respondents disagreed with item 18 and 71.1. \% disagreed with item 47. (See Table 3)

Table 3. Descriptive statistics of the open-mindedness subscale of pre-service mathematics teachers.

\begin{tabular}{llcc}
\hline No & Item & M & SD \\
\hline 5 & If there were four reasons in favor and one against. I'd go with the four. & 3.40 & 1.50 \\
7 & Tests that require thinking, not just memorization, are better for me. & 4.95 & 1.25 \\
15 & Being open-minded means you don't know what's true and what's not. & 3.89 & 1.73 \\
18 & Reading is something I avoid, if possible. & 4.50 & 1.65 \\
22 & Foreigners should study our culture instead of us always trying to & 3.65 & 1.68 \\
& understand theirs. & 2.50 & 1.48 \\
33 & I look for facts that support my views, not facts that disagree. & 3.61 & 1.68 \\
36 & Analogies are about as useful as a sailboat on a freeway. & 3.74 & 1.66 \\
41 & My opinion about controversial topics depends a lot on who I talk to last. & 4.22 & 1.71 \\
43 & The best way to solve problems is to ask someone else for the answers. & 3.75 & 1.75 \\
45 & Being open-minded about different world views is less important than & 4.45 & 1.76 \\
& people think. & 4.21 & 1.69 \\
\hline 7 & Things are as they appear to be & Others are entitled to their opinions, but I don't need to hear them & \\
\hline
\end{tabular}

Table 4 shows the mean scores of pre-service mathematics teachers for items on inquisitiveness subscale. Over $70 \%$ of students answered it was mostly true, true or completely true that they enjoyed trying to figure out how things work (item 38). Over $60 \%$ of students agreed with items 1, 30, 32 and 42. (See Table 4) 
Table 4. Descriptive statistics of the inquisitiveness subscale of pre-service mathematics teachers.

\begin{tabular}{llcc}
\hline No & Item & M & SD \\
\hline 1 & Studying new things all my life would be wonderful & 4.71 & 1.12 \\
8 & Others admire my intellectual curiosity and inquisitiveness. & 4.19 & 1.39 \\
30 & I look forward to learning challenging things. & 4.88 & 1.09 \\
31 & It makes a lot of sense to study what foreigners think. & 4.37 & 1.43 \\
32 & Being inquisitive is one of my strong points. & 4.72 & 1.30 \\
34 & Complex problems are fun to try to figure out. & 4.60 & 1.29 \\
38 & I really enjoy trying to figure out how things work. & 4.06 & 1.08 \\
42 & No matter what the topic, I am eager to know more about it. & 1.18 \\
\hline
\end{tabular}

Table 5 shows the mean scores of pre-service mathematics teachers for items on systematicity subscale. One item on the subscale had a mean score above 5.0. More than $75 \%$ of students answered it was mostly true, true or completely true that they were proud that they can think with great precision. Over $70 \%$ of students thought that it was easy for them to organize their thoughts. Over $70 \%$ of the respondents disagreed with item 9. (See Table 5)

Table 5. Descriptive statistics of the systematicity subscale of pre-service mathematics teachers.

\begin{tabular}{llcc}
\hline No & Item & M & SD \\
\hline 4 & I'm proud that I can think with great precision. & 5.09 & .96 \\
9 & I pretend to be logical, but I'm not. & 4.88 & 1.49 \\
10 & It's easy for me to organize my thoughts. & 4.63 & 1.12 \\
19 & People say I rush into decisions too quickly. & 3.80 & 1.68 \\
21 & When I have to deal with something really complex, it's panic time. & 3.28 & 1.54 \\
23 & People -think I procrastinate about making decisions. & 3.40 & 1.42 \\
\hline
\end{tabular}

Table 6 shows the mean scores of pre-service mathematics teachers for items on truth-seeking subscale. Only one item had a mean score above 4.0 with $66.2 \%$ of students thinking that the statement was mostly true, true or completely true. (See Table 6)

Table 6. Descriptive statistics of the truth-seeking subscale of pre-service mathematics teachers.

\begin{tabular}{llcc}
\hline No & Item & M & SD \\
\hline 6 & Most college courses cure uninteresting and not worth taking. & 3.29 & 1.79 \\
11 & Everyone always argues from their own self-interest, including me. & 3.26 & 1.70 \\
20 & Required subjects in college waste time. & 3.78 & 1.82 \\
25 & Being impartial is impossible when I'm discussing my own opinions. & 3.04 & 1.65 \\
27 & I believe what I want to believe. & 2.58 & 1.57 \\
28 & It's just not that important to keep trying to solve difficult problems. & 4.24 & 1.70 \\
49 & I know what I think, so why should I pretend to ponder my choices. & 3.05 & 1.46 \\
\hline
\end{tabular}

Table 7 shows the mean scores of pre-service mathematics teachers for items on analyticity subscale. The majority of students thought that some statements were mostly true, true or completely true. The highest mean score corresponds to item 46 which states that learning everything they can $(93.5 \%)$. Over $75 \%$ of students agreed with items 3, 13, 16, 17 and 26. (See Table 7) 
Table 7. Descriptive statistics of the analyticity subscale of pre-service mathematics teachers.

\begin{tabular}{llcc}
\hline No & Item & M & SD \\
\hline 2 & It bothers me when people rely on weak arguments to defend good ideas. & 4.90 & 1.32 \\
3 & I always focus the question before I attempt to answer it. & 5.24 & .84 \\
12 & It's important for me to keep careful records of my personal finances. & 4.48 & 1.61 \\
13 & When faced with a big decision, I first seek all the information I can. & 5.13 & .97 \\
16 & It's important for me to understand what other people think about things. & 5.19 & .92 \\
17 & I must have grounds for all my beliefs. & 5.08 & 1.03 \\
24 & People need reasons if they are going to disagree with another's opinion. & 5.02 & 1.01 \\
26 & I pride myself on coming up with creative alternatives. & 5.25 & .90 \\
37 & You could describe me as logical. & 4.64 & 1.22 \\
40 & Getting a clear idea about the problem at hand is the first priority. & 4.98 & 1.00 \\
46 & Learn everything you can, you never know when it could come in handy. & 5.27 & .97 \\
\hline
\end{tabular}

Table 8 shows the mean scores of pre-service mathematics teachers for items on self-confidence subscale. Over $80 \%$ agreed they took pride in their ability to understand the opinions of others. Only one item had a mean score below 4.0 with $23 \%$ of students thinking that the statement was mostly true, true or completely true. (See Table 8 )

Table 8. Descriptive statistics of the self-confidence subscale of pre-service mathematics teachers

\begin{tabular}{llcc}
\hline No & Item & M & SD \\
\hline 14 & My peers call on me to make judgments because I decide things fairly. & 4.44 & 1.22 \\
29 & Others look to me to establish reasonable standards to apply to decisions. & 4.22 & 1.25 \\
35 & I take pride in my ability to understand the opinions of others. & 4.72 & 1.08 \\
39 & Others look to me to keep working on a problem when the going gets tough. & 4.34 & 1.19 \\
44 & I'm known for approaching complex problems in an orderly way. & 4.41 & 1.15 \\
48 & Others look to me to decide when the problem is solved. & 3.62 & 1.31 \\
51 & I'm good at developing orderly plans to address complex problems. & 4.51 & 1.24 \\
\hline
\end{tabular}

\section{Research question 2}

An independent t-test was used to determine the differences in mean scores of males and females. Results indicated that there were significant differences between two groups on inquisitiveness $(\mathrm{t}=-2.16, \mathrm{p}=.03)$. Male students had higher means $(\mathrm{M}=4.79, \mathrm{SD}=.63)$ on the scale when compared to females $(\mathrm{M}=4.56, \mathrm{SD}=.71)$. The $95 \%$ confidence intervals for the difference in mean between groups was small for inquisitiveness scale. The Bonferroni adjustment procedure was used to avoid inflation of Type I error due to multiple testing. The level of significance was confirmed on the subscale.

Additionally, although female students had higher means $(\mathrm{M}=3.99, \mathrm{SD}=.79 ; \mathrm{M}=3.31, \mathrm{SD}$ $=.95 ; \mathrm{M}=5.02, \mathrm{SD}=.50 ; \mathrm{M}=4.32, \mathrm{SD}=.80)$ on open-mindedness, truth-seeking, analyticity, and self-confidence when compared to males $(\mathrm{M}=3.82, \mathrm{SD}=.74 ; \mathrm{M}=3.65, \mathrm{SD}=.86 ; \mathrm{M}=5.00$, $\mathrm{SD}=.49 ; \mathrm{M}=4.31, \mathrm{SD}=.80$ ), the differences were not significant in these subscales.

One-way Analysis of Variance (ANOVA) was used to determine the different effects of students' grade level on each subscale. Results showed that there were significant differences between two groups on the self-confidence subscale, $F(3,166)=3.40, p=.01$. The results of post hoc comparisons confirmed a significant difference in the mean scores of first year $(\mathrm{M}=$ $4.59, \mathrm{SD}=.83)$ and fourth year students $(\mathrm{M}=4.14, \mathrm{SD}=.68)$ on this subscale. 


\section{Research question 3}

The relationships among the six factors measured by the CCTDI were analysed by using Pearson correlation test. The results are presented in Table 10. It indicates the correlations among all six subscales; all are statistically significant. According to the results, the relationship between the self-confidence and inquisitiveness subscales was found the highest correlation ( $\mathrm{r}$ $=.551, \mathrm{p}=.00)$ and the relationship between the analyticity and truth-seeking subscales was found the lowest correlation $(\mathrm{r}=.330, \mathrm{p}=.00)$.

Table 10. Intercorrelations between the six subscales.

\begin{tabular}{lccllll}
\hline Subscales & 1 & 2 & 3 & 4 & 5 & 6 \\
\hline 1.Open-mindedness & - & - & - & - & - & - \\
2.Inquisitiveness & $.525^{*}$ & - & - & - & - & - \\
3.Systematicity & $.383^{* *}$ & $.359^{* *}$ & - & - & - & - \\
4.Truth-seeking & $.541^{* *}$ & .433 & $.475^{* *}$ & - & - & - \\
5.Analyticity & .342 & $.531^{* *}$ & $.391^{*}$ & .380 & - & - \\
6.Self-confidence & $.494^{* *}$ & $.551^{* *}$ & $.330^{* *}$ & $.510^{* *}$ & $.511^{* *}$ & - \\
\hline
\end{tabular}

Note. *Correlation is significant at the .05 level (2-tailed).

$* *$ Correlation is significant at the .01 level (2-tailed).

1 6: Subscales of CCTDI

\section{Discussion, implications, and limitations}

The study indicated that the CCTDI total scores of students ranged from 127 to 342 $(M=267.5)$. If the total score is between 240 to 300, the CTD level of participants are medium level (Kökdemir, 2003). Therefore, the pre-service mathematics teachers in this study had moderate CTD. The findings are consistent with those by Çevik (2013) and Şen (2009). They were in either partially or fully disagreement with the findings of Akgün and Duruk (2016), Beşoluk and Önder (2010), Çetinkaya (2011), Tümkaya (2011). Beşoluk and Önder (2010), for example, found that the majority of pre-service students $(68.0 \%)$ have medium CTD scores but $26.7 \%$ of pre-service students have low CTD scores (less than 240).

Regarding subscale scores, the analyticity $(M=5.02)$ and inquisitiveness $(M=4.67)$ subscales received the highest ratings of the six subscales. It is noticeable that seven items on the analyticity subscale had a mean greater than 5.0 and six items on inquisitiveness scale exceeded a mean score of 4.5. As can be seen clearly, the pre-service mathematics teachers have tendencies on reasoning, questioning, prediction potential difficulties. Also they may have intellectual curiosity and eagerness for learning. Tümkaya (2011) and Kartal (2012) reported similar results in their research. Kartal (2012), for example, found that the highest scores were analyticity and inquisitiveness subscales. On the other hand the highest score in other research was found self-confidence (Çevik, 2013) and open-mindedness subscales (Çetinkaya 2011; Yüksel, Uzun, \& Dost, 2013).

Based on self-confidence $(M=4.32)$ and systematicity $(M=4.18)$ subscale scores, pre-service students were moderately confident and systematic. Six out of seven items on the selfconfidence scale, for example, exceeded a mean score of 4.0. The findings indicated that the pre-service students may be able to trust themselves to make good judgements, successfully tackle problems and lead others in the logical solution of problems. In addition, they may improve organizational skills. 
On the other hand, the open-mindedness $(\mathrm{M}=3.90)$ and truth seeking $(\mathrm{M}=3.32)$ subscale received the lowest ratings of the six subscales. It is important to note that the highest item among these subscales that was item 7 with mean score $M=4.95$. Students thought that the tests that require thinking are better for them. Profetto-McGrath (2003) states that the reason for the low truth-seeking score is that many students may assume a passive posture and refuse to analyze new knowledge during lectures. According to Walter (2013), educators should avoid a didactic-oriented curriculum that is mainly a lecture style class and use a more problem based learning format.

Another result of the current study was that students' grade level influenced their levels of CTD. First year students felt more self-confident than fourth year students. The findings are consistent with the results of Çetinkaya (2011). However Akgün and Duruk (2016), Bakır (2015) and Tümkaya (2011) have different results in their research. Tümkaya (2011), for example, found that seniors' scores are significantly higher than the freshman's on the self-confidence subscales scores. On the other hand, Akgün and Duruk (2016) concluded that there was not a significant relationship between gender, grade, and school variables with CTD.

This study also indicated that gender differences had an effect on inquisitiveness subscales. Male students' scores are significantly higher than the female's on this subscales scores. Similar results were also evident in the literature (Zayıf, 2008). Çetinkaya (2011), however, reported that female students are significantly higher than male students on the analyticity, openmindedness and truth-seeking subscales scores. Yenice (2011) also found that pre-service science teachers' critical thinking disposition levels show significant difference based on gender in favor of female students in open mindedness subscale.

This study is limited with the participants in the study come from only one educational institution. Therefore, results may not generalize well to other institutions. Another limitation is that participants self-reported. The fact that the data is self-reported makes the responses subjective.

\section{Conclusion}

Critical thinking is an essential component of 21 st century higher order thinking abilities and disposition to think critically required for critical thinking and support the critical thinking process (Beyer, 1987; Facione, 1998). Thus, improving strong critical thinking disposition strategies should be a high priority (Çubukçu, 2006). The purpose of the present study was to investigate pre-service mathematics teachers' CTD. The findings indicated that the pre-service mathematics teachers have medium CTD levels. The results suggest that students were generally analytic $(M=5.02)$, inquisitive $(M=4.67)$, self-confident $(M=4.32)$ and systematic $(M=4.18)$. Students were moderately open-minded $(M=3.90)$ and truth seeking $(M=3.32)$. In addition, individual differences such as gender and grade can affect student CTD.

Given the findings in this study, students should be encouraged to enhance open-mindedness and truth-seeking dispositions. According to Ojevole (2013), developing open-mindedness disposition can be achieved by creating time for students to reflect upon their experience, promoting dialogue, and inquiring about actions. In addition, educators should integrate problem based activities in their lectures that can develop truth-seeking disposition. Cohen (2010) suggested that encouraging students to question personal biases and opinions that differ from others can promote this disposition. 
Although the study will contribute to the current knowledge base, CTD of pre-service mathematics teachers have yet to be explored. According to the results, further studies can design qualitatively and critical thinking development in the class can be probed. Research on individual differences has so far produced mixed results, so more research is required to determine under which conditions these differences occur. Additionally, it is recommended for future studies to investigate possible relationships between the individual differences and CTD, which would provide opportunities for further exploration. Researchers should investigate further to better understand the factors that may enhance development of critical thinking among pre-service mathematics teachers.

\section{References}

Abrami, P. C., Bernard, R. M., Borokhovski, E., Wade, A., Surkes, M., Tamim, R., \& Zhang, D. (2008). Instructional interventions affecting critical thinking skills and dispositions: A stage one meta-analysis. Review of Educational Research, 78(4), 1102-1134

Bakır, S. (2015). Critical thinking dispositions of pre-service teachers. Educational Research and Reviews, 10(2), 225-233.

Bell, R., Loon, M. (2015). The Impact of Critical Thinking Disposition on Learning Using Business Simulations. The International Journal of Management Education, 13, 119127.

Beşoluk, Ş. \& Önder, İ. (2010). Investigation of teacher candidates' learning approaches, learning styles and critical thinking dispositions. Ilkögretim Online, 9 (2), 679-693.

Beyer, B. (1987). Practical strategies for the teaching of thinking. Boston: Allyn and Bacon.

Browne, M. N., \& Litwin, J. L. (1987). Critical thinking in the sociology classroom: facilitating movement from vague objective to explicit achievement. Teaching Sociology, 15(4), 384-391.

Burbach, M. E., Matkin, G. S., Quinn, C. E., \& Searle, T. P. (2012). The impact of preparing agriculture faculty to influence student critical thinking disposition. Journal of Agricultural Education, 53(2), 1-14. DOI: 10.5032/jae.2012.02001

Çevik, (2013). S. An Investıgation of The Critıcal Thınkıng Dispositıons Of Pre-Service Teachers at A Private Non-Profit University. (Unpublished doctoral dissertation). Bilkent University, Ankara, Turkey.

Ennis, R. (1987). A taxonomy of critical thinking abilities and dispositions. In Teaching thinking skills: Theory and practice, ed. J. Baron and R. Sternberg. New York: W.H. Freeman.

Facione, P. A. (1990). Critical thinking: A statement of expert consensus for purposes of educational assessment and instruction. Millbrae, CA: The California Academic Press.

Facione, P. A. (1998). Critical thinking: What it is and why it counts - A reference paper.Milbrae, CA: The California Academic Press. Retrieved from

www.insightassessment.com/pdf_files/what\&Why98.pdf

Facione, P. A., \& Facione, N. C. (1992). The California critical thinking dispositions inventory (CCTDI); and the CCTDI test manual. Millbrae, CA: California Academic Press.

Facione, P. A., Sanchez, C. A., Facione, N. C., \& Gainen, J. (1995). The disposition toward critical thinking. The Journal of General Education, 44 (1), 1-25.

Güven, M. \& Kürüm, D. (2008). The relationship between teacher candidates' learning styles and critical thinking dispositions. Elementary Education Online, 7(1), 53-70.

Halpern, D. (2003). Thought and knowledge, 4th ed. Mahwah, NJ: Erlbaum. 
Hill, J. L., \& Nelson, A. (2011). New technology, new pedagogy? Employing video podcasts in learning and teaching about exotic ecosystems. Environmental Education Research, 17(3), 393-408. doi:10.1080/13504622.2010.545873.

Huang, Y., \& Yeh, M. (2010). Exploring critical thinking in clinical nurses. International Nursing Research Congress, Retrieved from http://hdl.handle.net/10755/152910

Incikabi, L., Tuna, A., \& Biber, A. C. (2013). An analysis of mathematics teacher candidates' critical thinking dispositions and their logical thinking skills. Journal of International Education Research, 3(9), 257-266.

King, P.M., Wood, P. K., \& Mines, R. A. (1990). Critical thinking among college and graduate students. The Review of Higher Education, 13(2), 167-186.

Kong, L., Qin, B., Zhou, Y., Mou, S., \& Gao, H. (2014). The effectiveness of worked-example based learning on development of nursing students' critical thinking: A systematic review and meta-analysis. International Journal of Nursing Studies, 51, 458-469.

Kökdemir, D. (2003). Decision Making and Problem Solving under Uncertainty. Unpublished doctoral dissertation, Ankara University, Ankara.

Kuhn, D. (1999). A developmental model of critical thinking. American Educational Research Association, 28(2), 16-25.

Lane-Patrice, L. A. (2013). Enhancing critical thinking, writing and disposition preparedness amongst four-year university teacher education student. (Doctoral dissertation). Available from ProQuest Dissertations and Theses database. (UMI No.3590536).

Lewis, C. Y. (2012). Critical Thinking Dispositions of Tennessee Agriculture Teachers. (Doctoral dissertation). Available from Proquest Dissertation and Theses database UMI No. 1510436.

Naber, Jessica; Wyatt, Tami H. The effect of reflective writing interventions on the critical thinking skills and dispositions of baccalaureate nursing students. Nurse Education Today, 34. 1 (2014): 67-72.

Ojewole, F. O. (2013). Critical thinking dispositions of undergraduate nursing students and nursing faculty in southwestern. (Doctoral dissertation). Available from ProQuest Dissertations and Theses database. (UMI No.3597809).

Özdener, N., \& Güngör, Y. (2010). Effects of video podcast technology on peer learning and project quality. Procedia Social and Behavioral Sciences 2, 2217-2221.

Partnership for 21st Century Skills. (2011). Learning for the 21st century: A report and mile guide for 21st century skills. Retrieved from. http://www.p21.org/storage/documents/ P21CommonCoreToolkit.pdf.

Siegel, H. (1988). Educating reason: Rationality, critical thinking and education. New York: Routledge.

Skiba, D. J. (2006). The 2005 Word of the year: Podcast. Nursing Education Perspectives, 27(1), 54-55.

Moore, T. (2013). Critical thinking: seven definitions in search of a concept. Studies in Higher Education, 38(4), 506-522.

Özdemir, S., M. (2005). Assessing university students' critical thinking skills for some variables. Journal of Turkish educational science, 3(3): 1-17.

Profetto-McGrath, J. (2003). The relationship of critical thinking skills and critical thinking dispositions of baccalaureate nursing students. Journal of Advanced Nursing, 42(6), $569-577$.

Tümkaya, S. (2011). Comparison of college science major students' learning styles and critical thinking disposition. Journal of Kırşehir Education Faculty, 12 (3), 215-234. 
Walter, J.M. (2013). An Assessment of Post-Professional Athletic Training Students' Critical Thinking Skills and Dispositıons. (Doctoral dissertation). Available from ProQuest Dissertations and Theses database. (UMI No. 3579606).

Wan, Y., Lee, D. T. F, Lee, I. F. K., Chau, J. P. C,, Wootton, Y. S. Y., \& Chang, A. M.(2000). Disposition towards critical thinking: a study of Chinese undergraduate nursing students. Journal of Advanced Nursing, 52(1), 84-90. doi: 10.1046/j. 13652648.2000.01417.x

Yüksel, N. S., Uzun, M. S., \& Dost, Ş. (2013). Critical thinking tendencies of prospective mathematics teachers. Hacettepe Üniversitesi Eğitim Fakültesi Dergisi, Özel Sayı(1), 393-403.

Zayif, K. (2008). Critical thinking disposition of pre-service teachers. (Unpublished master thesis). Abant İzzet Baysal University, Bolu, Turkey.

Şen, Ü. (2009). Determination of Turkish education teacher candidates' views related to critical thinking. Zeitschrift für die Welt der Türken Journal of World of Turks. 1(2), 69-89. 